\title{
Corrosion Behavior of Ni-Cr Dental Casting Alloys
}

\author{
Porojan Liliana ${ }^{1, *}$, Savencu Cristina Elena ${ }^{1}$, Costea Liviu Virgil ${ }^{2}$, Dan Mircea Laurențiu ${ }^{2}$, \\ Porojan Sorin Daniel ${ }^{3}$ \\ ${ }^{1}$ Department of Dental Prostheses Technology (Specialization Dental Technology), Faculty of \\ Dentistry, "V. Babeş" University of Medicine and Pharmacy, Timişoara, Romania \\ ${ }^{2}$ CAICAM Department, Faculty of Industrial Chemistry and Environmental Engineering, Politehnica \\ University, Timişoara, Romania \\ ${ }^{3}$ Department of Oral Rehabilitation (Specialization Dental Technology), Faculty of Dentistry, "V. \\ Babeş" University of Medicine and Pharmacy, Timişoara, Romania \\ *E-mail: lilianasandu@gmail.com
}

doi: $10.20964 / 2018.01 .08$

Received: 22 June 2017 / Accepted: 19 October 2017 / Online Published: 1 December 2017

Nickel-chromium (Ni-Cr) alloys have been used for dental prostheses because of their low prices and excellent properties in veneered restorations. While most $\mathrm{Ni}-\mathrm{Cr}$ restorations perform well clinically, corrosion products and components of these alloys are known to have the potential to cause hypersensitivity and other tissue reactions. The aim of this study was to investigate the corrosion behavior of four different commercial Ni-Cr dental casting alloys (S1, S2, S3, S4) in simulated oral environment, related to the chemical composition and microstructure, by electrochemical methods, including electrochemical impedance spectroscopy (EIS), chronoamperometric and chronopotentiometric investigation, cyclic voltammetry studies. Samples surface characterization was done using scanning electron microscopy (SEM) before and after immersion in artificial saliva. Corroborating the results of the investigation methods, $\mathrm{Ni}-\mathrm{Cr}$ alloys represent a suitable alternative for metal frameworks used in prosthetic dentistry. All dental alloys exhibit low corrosion tendency, but S1 and S2 alloys were most stable to corrosion in artificial saliva. The best electrochemical behavior has to be attributed to the composition of the alloys (containing $\mathrm{Cr}$ and $\mathrm{Mo}$ ) and to the compact surface microstructure.

Keywords: Nickel-Chromium dental casting alloys, corrosion behavior, chemical composition, microstructure

\section{FULL TEXT}

(C) 2018 The Authors. Published by ESG (www.electrochemsci.org). This article is an open access article distributed under the terms and conditions of the Creative Commons Attribution license (http://creativecommons.org/licenses/by/4.0/). 